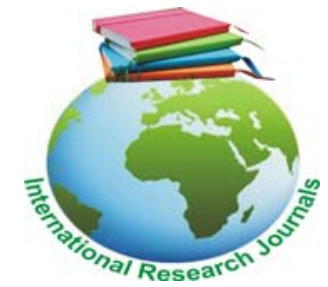

African Journal of Food Science and Technology ((ISSN: 2141-5455) Vol. 6(2) pp. 68-74, February, 2015

DOI: http:/dx.doi.org/10.14303/ajfst.2015.021

Available online @http://www.interesjournals.org/AJFST

Copyright (C2015 International Research Journals

Full Length Research Paper

\title{
Moringa oleifera, Gliricidia sepium and Leucena leucocephala ensiled with molasses as additive: effect on feed intake and digestibility in yankasa rams
}

\author{
Aye P.A \\ Department of Animal Production and Health Sciences Ekiti State University, Ado- Ekiti \\ Corresponding email:amokapius@yahoo.com
}

\begin{abstract}
The nutritional potential of molasses ensiled Moringa oleifera, Gliricidia sepium and Leucaena leucocephala as additives were compared by feeding them to twenty-four yearling Yankasa rams for twelve weeks. The rams were assigned randomly to four treatments. The feed intake, feed conversion ratio, body weight changes and nutrient digestibility as influenced by the four dietary treatments were evaluated. The mean weight gain of rams fed Giliricidia sepium ensiled with cassava peels $(2.4 \mathrm{~kg})$, Leucaena leucocephaala ensiled with cassava peels $(2.2 \mathrm{~kg})$ and Moringa oleifera ensiled with cassava peels $(2.1 \mathrm{~kg})$ were significantly $(P<0.05)$ higher than those fed control diet of ensiled cassava peels only (1.8kg). Rams fed diet of cassava peels ensiled only had the least feed conversion ratio of 13.35 while rams fed supplemental Gliricidia sepium, Leucaena leucocephala and Moringa oleifera ensiled with cassava peels had feed conversion ratio of $10.35,11.29$ and 12.0 respectively. The highest feed conversion ratio was observed in rams fed supplemental Gliricidia sepium ensiled with cassava peels (10.35). The nitrogen balance values for rams on treatments CP+ GS $\left(4.29 \mathrm{~g} \mathrm{day}^{-1}\right), \mathrm{CP}+\mathrm{LL}\left(4.02 \mathrm{~g} \mathrm{day}^{-1}\right)$ and $C P+M O\left(3.64 \mathrm{~g} \mathrm{day}^{-1}\right)$ were significantly $(P<0.05)$ higher than those rams on control diet of ensiled cassava peels only. Rams on treatment CP+GS $\left(54.1 \mathrm{~g} \mathrm{day}^{-1}\right), \mathrm{CP}+\mathrm{LL}\left(50.4 \mathrm{~g} \mathrm{day}^{-1}\right)$ and $\mathrm{CP}+\mathrm{MO}\left(47.9 \mathrm{~g} \mathrm{day}^{-1}\right.$ )had significant $(\mathrm{P}<0.05)$ higher values of $\mathrm{N}$-retention than those rams on control treatment $\left(36.1 \mathrm{~g} \mathrm{day}^{-1}\right)$. The nutrient digestibility of dry matter $(61.83 \%)$, crude protein $(60.73 \%)$, ether extract $(60.73 \%)$, nitrogen free extract $(68.0 \%)$ and crude fibre $(63.70 \%)$ of rams on control diet were consistently lower $(P<0.05)$ than those rams fed supplemental Gliricidia sepium, Leucaena leucocephala and Moringa oleifera ensiled materials. Rams fed Giliricidia sepium, Leucaena leucocephala and Moringa oleifera ensiled cassava peels had better feed intake, rumen digestion and growth performance compared to rams fed control diet of ensiled cassava peels only.
\end{abstract}

Key words: Digestibility, conversion ratio, Growth rate, Nitrogen retention, Additives

\section{INTRODUCTION}

Sheep play a significant role in livelihoods of the rural dwellers in most less developed countries. Apart from serving as a vital protein source, it provides income for meeting urgent household needs (Peacock et al., 2005). Yankasa sheep is a native breed of sheep which occurs in the Sahel, Sudan and Guinea savannah zones of Nigeria. They are commonly fed with grasses, and the poor feeding regime has affected the growth rate and performance of Yankasa sheep. With the perpetual increase in population of livestock in Nigeria, the use of non-conventional feeds is gaining ground. Previously, livestock were fed on grains as the main source of energy and soybean meal, fish meal, etc. as sources of protein. This practice has put the livestock industry into direct competition with man for these feed materials (Muriu et al., 2002) thereby hindering the productivity of small ruminants; hence, shortage of animal proteins.

Livestock production is plagued with so many problems which include; low productivity of animals, poor management systems, poor genetic make-up of 
indigenous animals, non-availability of feed ingredients, shortage of good quality feeds and many more. Furthermore the limited supply of raw materials for livestock feed industry has resulted in a continuous increase in the cost of production.

However, during the dry season, scarcity of forages is common problem limiting sheep production in the tropical areas (Nwaigwe, 2011).There is shortage of good quality feed needed to sustain this sheep growth and this causes a major constraints to sheep production which can be solved by finding alternative and adequate sources of protein and energy in the concentrate mixture given to these animals. Browse plants can be considerably made use of and these browse plants can be Moringa oleifera, Gliricidia sepium and Leucaena leucoceephala.

Experience in other countries has shown that Moringa oleifera can be used as supplement for improving the productivity of sheep which are dependent on low quality roughages as their main diet (Makker and Becker, 1997; Aregheore, 2002).

Moringa oleifera also known as drumstick treet is a well-known tree in West Africa especially in semi-arid areas where it is often cultivated as a living fence around people's garden and consumed in various forms as food. The leaves are high in protein, vitamin A and C. Its fruits, flowers and leaves all contain $5-10 \%$ of protein on the average. However, according to Akinbamijo et al. (2004) the value of the tree and its benefits as a highly supplement to low quality roughages in ruminant feeding system have not been fully known nor widely exploited.

Gliricidia sepium is an extremely versatile plant which can fulfill a number of roles in human nutrition and small holder agricultural production system. Gliricidia is used as a green fodder/protein supplement to low-quality forages and by-products for cattle, sheep and goats.

Leucaena leucoceephala is known for its nutrient density, when fed to livestock. It meets their nutrient requirements for growth and other productive purposes (Ekpenyong, 1986). The leaves are palatable and preferentially eaten by animals (Malini et al., 1989).

Molasses which is extremely palatable and an excellent source of energy with appetizer when restricted to a level of $15 \%$ (Hassoun and $\mathrm{Ba}, 1991$ ). In addition to its use as source of energy, it is also used as a binder to reduce dustiness of ration, to stimulate rumen microbial activity, to serve as a carrier for non-protein nitrogen (NPN) and vitamins in liquid supplement. It also serves as an additive that aids feed intake.

Molasses when used in the process of ensiling reduces the ensiling period, improves the quality of ensiled material, enhance the lactic acid production during fermentation and increase the nitrogen content of the ensiled material.

The objective of this study is to evaluate the effect of Moringa oleifera, Gliricidia sepium and Leucaena Leucocephala ensiled with molasses as additive on performance characteristics of Yankasa rams

\section{MATERIALS AND METHODS}

\section{Experimental Site}

The experiment was carried out at the small ruminants unit of the Teaching and Research Farm of the Ekiti State University, Ado-Ekiti.

The animals were quarantined for 4 weeks and data were collected for 12 weeks. The pens used were cleaned and disinfested with germicide, cleaning of feeders and water troughs were also carried out before the arrival of the animals.

\section{Procurement of Yankasa Rams}

Twenty-four yearling rams were purchased from the open markets in Lokoja, Kogi State of Nigeria. They were quarantined for 4 weeks during which routine treatment developed at NAPRI (1984) and modified by Aye (1998) was applied.

\section{Experimental Layout and Animal Management}

The pen was partitioned into twenty-four equi-dimentional units with plants. The rams were weighed into their experimental units; efforts were made to ensure that all the treatments were balanced in the body weight. The design of the experiment was a completely randomized design. The animals were randomly assigned to 4 treatments and each treatment has 3 replicates of 2 animals each. The rams were fed cassava peels and Panicum maximum as the basal diets and experimental diets of ensiled Moringa oleifera, Gliricidia sepium and Leucaena leucocephala with molasses as additive. The treatments were as follows:

Treatment 1: Control diet of ensiled cassava peels only

Treatment 2: $50 \%$ Cassava peels ensiled with 50\% Gliricidia sepium.

Treatment 3: $50 \%$ Cassava peels ensiled with 50\% Leucaena leucocephala.

Treatment 4: $\quad 50 \%$ Cassava peels ensiled with $50 \%$ Moringa oleifera.

\section{Feeds}

Fresh cassava peels were obtained from Aba Ibira in Iworoko Ekiti. The fresh cassava peels were sun dried for about 5-7 days depending on the weather condition.

Panicum maximum was harvested 1 metre from the base of the plant with sickle. The stem and leaves were still succulent and not lignified. It was chopped into small pieces with a cutlass so as to prevent wastage by the animals; the grass was wilted for about 2 days to prevent scouring in animals. 
The leaves of Moringa oleifera, Gliricidia sepium and Leucaena leucocephala were harvested from their plantations at the Teaching and Research Farm, Ekiti State University. The leaves were ensiled with cassava peels using molasses as an additive.

\section{Feeding Trial}

The feeding trials were divided into two periods viz: preliminary period and feeding trial proper. The preliminary period lasted 7 days during which the animals were allowed to adjust to the experimental diets. Feeding trial period of 12 weeks when animals were fed basal diets containing cassava peels and Panicum maximum supplemented with ensiled Moringa oleifera, Gliricidia sepium and Leucaena leucocephala with molasses as an additive.

Measured quantities of basal diet and the experimental diets were offered to the animals each day and the quantity left were weighed the following morning to determine daily feed intake. The volume of water was taken using a measuring cylinder before and after drinking and the water intake was recorded as daily water intake.

\section{Growth rate}

The weights of the animals were determined using Salter scale. Weights of the animals were taken at the beginning of the feeding trial and subsequently every week for an assessment of growth rate.

\section{Nutrient utilization}

This was carried out by transferring rams into wooden metabolic cage fitted with facilities for separate collection of urine and faeces. Each ram was allocated to individual metabolic cage for 21 days. The feed offered, faeces and urine were collected for analysis.

The animals were acclimatized for a period of 14 days. Collection period for balance studies lasted for 7 days. The animals were fed on basal diets of Panicum maximum supplemented with Moringa oleifera, Gliricidia sepium and Leucaena leucocephala ensiled with cassava peels. Weight of the basal and experimental diets were taken before and after feeding for 7 days and the feed intake recorded. Clean and fresh water volume taken before and after drinking and the water intake determined for 7 days. $20 \mathrm{~cm}^{3}$ of $10 \%$ concentrated $\mathrm{H}_{2} \mathrm{SO}_{4}$ was added to each bowl which was used to collect the urine of animals to prevent Nitrogen loss and bacteria growth infestation. The volume of urine was measured and recorded daily each morning. $10 \%$ of the urine collected from each animal was poured into a well-labeled urine collection bottle and kept in freezing cabinet prior to laboratory analysis. The faeces were collected from individual animal. $10 \%$ of the faeces collected immediately the faeces were voided daily over the 7-day period were bulked and weighed and used for moisture determination. The remaining faeces were oven dried at $70^{\circ} \mathrm{C}$ for 36 hours, milled and stored in air tight bottles.

\section{Analytical procedure}

Dried milled sample of feeds and faeces were analysed for their proximate composition according to AOAC (2005). Nitrogen contents of feed, faeces and urine were determined by the micro-kjeldahl technique using the Marham's distillation apparatus. Results obtained were used for the calculation of digestibility of nutrients and nitrogen balance for the experimental animals.

\section{Statistical Analysis}

Data collected were subjected to ANOVA the GLM (general linear model) option Minitab software version 13.2 (Steel and Torrie, 1980). Means were separated using Duncan's Multiple Range Test (Duncan, 1955).

\section{RESULTS AND DISCUSSION}

\section{Experimental Diet Composition}

Table 1. shows the proximate composition of the ensiling materials used in the study.

Cassava peels used in this study contained $85.7 \%$ dry matter (DM), $6.5 \%$ crude protein (CP), $22.6 \%$ fibre (CF), 1.1\% ether extract (EE), 58.3\% nitrogen free extract (NFE) and 3.80\% Ash.

The Gliricidia sepium used contained $78.56 \%$ dry matter (DM), $27.40 \%$ crude protein (CP), $15.80 \%$ crude fibre (CF), $5.80 \%$ either extract (EE), 39.50\% nitrogen free extract (NFE) and $5.8 \%$ ash.

The Leucaena leucocephala used contained $84.50 \%$ (DM), 26.58\% (CP), 14.96\% (CF), 6.20\% (CE), 37.83\% (NFE) and $4.60 \%$ ash.

The Moringa oleifera used contained $84.32 \%$ DM, 23.58\% CP, $12.83 \%$ CF, $6.30 \%$ EE, $32.64 \mathrm{NFE}$ and $5.10 \%$ Ash.

Table 2. shows the proximate composition of silage made from cassava peels, Moringa oleifera, Gliricidia sepium and Leucaena leucocephala.

The ensiled cassava peel only, used in the study contained $26.59 \%$ dry matter (DM), 5.2\% crude protein (CP), $18.56 \%$ crude fibre (CF), $0.86 \%$ ether extract (EE), $60.30 \%$ nitrogen free extract (NFE), 2.85\% ash, $0.32 \%$ $\mathrm{Ca}\left(\mathrm{mgkg}^{-1}\right), 0.11 \% \mathrm{P}\left(\mathrm{mg} \mathrm{kg}^{-1}\right)$ and $\mathrm{pH}$ of 5.1 . 
Table 1. Proximate composition of ensiling materials ( 100\%)

\begin{tabular}{lllll}
\hline Constituent & Cassava Peels & Gliricidia sepium & $\begin{array}{l}\text { Leucaena } \\
\text { leucocephala }\end{array}$ & Moringa oleifera \\
\hline Dry matter & 85.9 & 78.56 & 84.50 & 84.32 \\
Crude protein & 6.5 & 27.40 & 26.58 & 23.58 \\
Crude fibre & 22.6 & 15.80 & 14.96 & 12.83 \\
Ether extract & 1.1 & 5.80 & 6.20 & 6.30 \\
NFE & 58.3 & 39.50 & 37.83 & 32.64 \\
Ash & 3.80 & 5.8 & 4.60 & 5.10 \\
\hline
\end{tabular}

Table 2. Proximate composition of silages made from cassava peels, Gliricidia sepium, Leucaena leucocephala and moringa oleifera

\begin{tabular}{|c|c|c|c|c|c|}
\hline Constituent & Cassava Peels & CP + GS & $\mathrm{CP}+\mathrm{LI}$ & $\mathrm{CP}+\mathrm{M}$ & SEM \\
\hline Dry matter $\left({\left.\mathrm{g} 100 \mathrm{~g}^{-1}\right)}^{-1}\right.$ & 26.59 & 32.26 & 34.56 & 32.65 & 0.82 \\
\hline Crude protein $\left(\mathrm{g}_{\left.100 \mathrm{~g}^{-1}\right)}\right.$ & $5.20^{\mathrm{c}}$ & $22.23^{\mathrm{a}}$ & $23.17^{\mathrm{a}}$ & $20.32^{\mathrm{b}}$ & 1.7 \\
\hline Crude fibre $\left({\left.\mathrm{g} 100 \mathrm{~g}^{-1}\right)}^{2}\right.$ & $18.56^{a}$ & $12.56^{\mathrm{b}}$ & $12.03^{\mathrm{b}}$ & $12.65^{\mathrm{b}}$ & 0.38 \\
\hline Ether extract $\left(\mathrm{g} 100 \mathrm{~g}^{-1}\right)$ & $0.86^{\mathrm{c}}$ & $3.20^{\mathrm{b}}$ & $3.56^{\mathrm{b}}$ & $4.02^{\mathrm{a}}$ & 0.31 \\
\hline $\operatorname{NFE}\left(\mathrm{g} 100 \mathrm{~g}^{-1}\right)$ & $60.30^{\mathrm{a}}$ & $36.50^{\mathrm{b}}$ & $33.80^{\mathrm{b}}$ & $34.56^{\mathrm{b}}$ & 0.69 \\
\hline Ash $\left(\mathrm{g} \mathrm{100 \textrm {g } ^ { - 1 } )}\right.$ & $2.85^{\mathrm{c}}$ & $4.20^{\mathrm{a}}$ & $3.80^{\mathrm{b}}$ & $4.26^{\mathrm{a}}$ & 2.36 \\
\hline $\mathrm{Ca}\left(\mathrm{mg} \mathrm{Kg}^{-1}\right)$ & $0.32^{\mathrm{b}}$ & $0.30^{\mathrm{b}}$ & $0.28^{\mathrm{b}}$ & $0.19^{\mathrm{a}}$ & 0.10 \\
\hline$P(\mathrm{mg} \mathrm{kg}-1)$ & 0.11 & 0.11 & 0.10 & 0.10 & 0.05 \\
\hline $\mathrm{PH}$ & 5.1 & 4.8 & 4.7 & 5.0 & 0.05 \\
\hline
\end{tabular}

$a, b, c$ Means with different superscript on the same row are significantly different $(P<0.05)$.

CP - Cassava Peels, GS - Gliricidia sepium, LI - Leucaena leucocephala, MO - Moringa oleifera

Table 3. Growth performance of yankasa rams fed ensiled materials

\begin{tabular}{|c|c|c|c|c|c|}
\hline Parameters & CP & CP + GS & $\mathrm{CP}+\mathrm{LI}$ & $\mathrm{CP}+\mathrm{M}$ & SEM \\
\hline Initial weight (kg) & 17.20 & 16.80 & 17.00 & 16.60 & 0.60 \\
\hline Final weight $(\mathrm{kg})$ & 19.00 & 19.20 & 19.20 & 18.70 & 1.20 \\
\hline Weight gain (kg) & 1.8 & 2.4 & 2.2 & 2.1 & 0.90 \\
\hline Weight gain (g/day) & 21.43 & 28.57 & 26.20 & 25.00 & 1.40 \\
\hline Initial $w^{0.75}(\mathrm{~kg})$ & 8.5 & 8.3 & 8.4 & 8.2 & 1.15 \\
\hline Final $\mathbf{w}^{0.75}(\mathrm{~kg})$ & 9.1 & 9.2 & 9.2 & 9.0 & 1.20 \\
\hline$w^{0.75}$ gain $(\mathrm{kg})$ & 0.6 & 0.9 & 0.8 & 0.8 & 1.22 \\
\hline DM intake (g/day) & $286^{c}$ & $307^{a}$ & $296^{b}$ & $300^{b}$ & 8.22 \\
\hline Feed Conversion Ratio & 13.35 & 10.35 & 11.29 & 12.0 & 0.92 \\
\hline
\end{tabular}

$a, b, c$ Means with different superscript on the same row are significantly different $(P<0.05)$

The Gliricidia sepium ensiled cassava peels used contained $32.26 \%$ dry matter (DM), $22.23 \%$ crude protein (CP), $12.56 \%$ crude fibre (CF), $3.20 \%$ ether extract (EE), $36.50 \%$ nitrogen free extract (NFE), $4.2 \%$ ash, $0.30 \%$ $\mathrm{Ca}\left(\mathrm{mgkg}^{-1}\right), 0.11 \% \mathrm{P}\left(\mathrm{mg} \mathrm{kg}^{-1}\right)$ and $\mathrm{pH}$ of 5.1 .

The Leucaena leucocephala ensiled cassava peels used contained $34.56 \%$ dry matter (DM), $25.17 \%$ crude protein (CP), $12.03 \%$ crude fibre (CF), $3.56 \%$ ether extract (EE), $33.80 \%$ nitrogen free extract (NFE), 3.80 ash, $0.28 \% \mathrm{Ca}\left(\mathrm{mgkg}^{-1}\right), 0.10 \% \mathrm{P}\left(\mathrm{mg} \mathrm{kg}^{-1}\right)$ and $\mathrm{pH}$ of 4.7 .

The Moringa oleifera ensiled cassava peels used contained $32.65 \%$ dry matter (DM), $20.32 \%$ crude protein (CP), $40.02 \%$ crude fibre (CF), $4.02 \%$ ether extract (EE),
$34.56 \%$ nitrogen free extract (NFE), 4.26\% ash, 0.19\% $\mathrm{Ca}\left(\mathrm{mgkg}^{-1}\right), 0.10 \% \mathrm{P}\left(\mathrm{mg} \mathrm{kg}^{-1}\right)$ and $\mathrm{pH}$ of 4.7 .

\section{Body weight changes}

Table 3. shows the effect of the various dietary treatments on the live weight gain, feed conversion ratio and dry matter intake (DMI) of Yankasa rams. The dry matter intake (DMI) of rams fed ensiled cassava peels (control) only, Gliricidia sepium ensiled with cassava peels, Leucaena leucocephala ensiled with cassava peels and Moringa oleifera ensiled with cassava peels 
Table 4. mean intake of yankasa rams fed ensiled materials

\begin{tabular}{lllll}
\hline & Cassava Peels (control) & CP + GS & CP + LI & CP + MO \\
\hline & 2.5 & 2.3 & 2.0 & 1.7 \\
& 1.7 & 1.9 & 1.5 & 1.6 \\
& 2.5 & 1.9 & 1.5 & 1.7 \\
& 2.1 & 1.5 & 1.0 & 1.0 \\
& 3.1 & 2.3 & 1.6 & 2.0 \\
& 2.9 & 2.5 & 0.8 & 1.4 \\
Mean & 3.1 & 3.0 & 0.8 & 1.7 \\
SD & 2.55 & 2.2 & 1.31 & 1.65 \\
CV & 0.52 & 0.49 & 0.46 & 0.31 \\
\hline
\end{tabular}

Table 5. Nutrient digestibility of yankasa rams fed ensiled materials

\begin{tabular}{llllll}
\hline Parameters & CP & CP + GS & CP + LI & CP + M & SEM \\
\hline Dry matter \% & $61.83^{\mathrm{c}}$ & $68.26^{\mathrm{a}}$ & $69.40^{\mathrm{a}}$ & $66.0^{\mathrm{b}}$ & 2.80 \\
Crude protein \% & $60.73^{\mathrm{c}}$ & $70.39^{\mathrm{a}}$ & $65.85^{\mathrm{b}}$ & $65.0^{\mathrm{b}}$ & 6.79 \\
Crude fibre \% & $63.70^{\mathrm{a}}$ & $59.32^{\mathrm{b}}$ & $64.48^{\mathrm{a}}$ & $59.20^{\mathrm{b}}$ & 5.86 \\
Ether extract \% & $60.73^{\mathrm{c}}$ & $67.39^{\mathrm{a}}$ & $61.62^{\mathrm{c}}$ & $63.90^{\mathrm{b}}$ & 6.79 \\
NFE \% & $68.0^{\mathrm{b}}$ & $75.32^{\mathrm{a}}$ & $76.50^{\mathrm{a}}$ & $68.56^{\mathrm{b}}$ & 6.83 \\
\hline
\end{tabular}

$a, b, c$ Means with different superscript on the same row are significantly different $(P<0.05)$.

were $286 \mathrm{~g}_{\text {day }}{ }^{-1}, 307 \mathrm{~g} \mathrm{day}^{-1}, 296 \mathrm{~g}_{\text {day }^{-1}} 300 \mathrm{~g} \mathrm{day}^{-1}$ respectively with the animals fed supplemental Gliricidia sepium ensiled with cassava peels having the highest dry matter intake of $307 \mathrm{~g} \mathrm{day}^{-1}$. The weight gain of the rams fed control diet of cassava peels ensiled only was significantly lower $(p<0.05)(1.8 \mathrm{~kg})$ compared to those rams fed ensiled CP + GS, CP + $\mathrm{LI}$ and $\mathrm{CP}+\mathrm{MO}(2.4 \mathrm{~kg}$, $2.2 \mathrm{~kg}$ and $2.1 \mathrm{~kg}$ respectively). The metabolic weight gain of rams were $0.6 \mathrm{~kg}, 0.9 \mathrm{~kg}, 0.8 \mathrm{~kg}$ and $0.8 \mathrm{~kg}$ for rams fed ensiled cassava peels only, ensiled CP+ GS, CP + LI and $\mathrm{CP}+\mathrm{MO}$ respectively. The feed conversion ratio of rams fed experimental diets of ensiled cassava peels only, ensiled CP + GS, CP + $\mathrm{LI}$ and $\mathrm{CP}+\mathrm{MO}$ were 13.35, $10.53,11.29$ and 12.0 respectively. The supplemental ensiled materials were significantly $(P<0.05)$ different the control treatment.

\section{Feed intake}

Table 4 shows the mean feed intake of rams fed experimental diets of ensiled cassava peels only (control), Gliricidia sepium ensiled with cassava peels, Leucaena leucocephala ensiled with cassava peels and Moringa oleifera ensiled with cassava peels. The mean feed intake of rams fed ensiled CP + GS, CP + LI and CP $+\mathrm{MO}$ were $2.2 \pm 0.49,1.31 \pm 0.45$ and $1.65 \pm 0.31$ respectively which were lower than the mean feed intake of rams fed control diet of ensiled cassava peels only ( $2.55 \pm 0.52$ ). This reveals that the experimental diets of ensiled $\mathrm{CP}+\mathrm{GS}, \mathrm{CP}+\mathrm{LI}$ and $\mathrm{CP}+\mathrm{MO}$ enhance better performance than the control diet of ensiled cassava peels only.

\section{Rumen digestibility}

The dry matter (DM) and Nitrogen free extract (NFE) of Yankasa ram fed Leucaena leucocephala ensiled with cassava peels of $69.40 \%$ (DM) and $76.5 \%$ (NFE) were higher than those rams fed ensiled cassava peels only Gliricidia sepium ensiled with cassava peels and Moringa oleifera ensiled with cassava peels had $61.83 \%$ (DM) and $68 \%$ (NFE), 68.26\% (DM and $75.32 \%$ (NFE) and $66.0 \%$ (DM) and $68.56 \%$ (NFE) respectively.

The crude protein (CP) of rams fed ensiled CP + GS was significantly $(P<0.05)$ higher $(70.39 \%)$ than those rams fed ensiled cassava peels only, $\mathrm{CP}+\mathrm{LI}$ and $\mathrm{CP}+$ MO (60.37\%, 65.85\% and 65.0\% respectively).

The crude fibre of rams fed ensiled cassava peels only and ensiled $\mathrm{CP}+\mathrm{LI}$ at $64.48 \%$ were significantly $(p<0.05)$ higher than those rams fed ensiled CP + GS and $\mathrm{CP}+\mathrm{MO}$ (59.32\% and 59.20\% respectively).

The digestibility coefficient of Ether Extract (EE) values of rams fed the experimental diet of ensiled CP + GS was significantly $(p<0.05)$ higher $67.3 \%$ than those rams fed ensiled cassava peels only, $\mathrm{CP}+\mathrm{LI}$ and $\mathrm{CP}+\mathrm{MO}$ that had $60.73 \%, 61.62 \%$ and $63.90 \%$ respectively.

\section{Nitrogen utilization}

The nitrogen utilization of ensiled cassava peels only, ensiled $\mathrm{CP}+\mathrm{GS}$, ensiled $\mathrm{CP}+\mathrm{LI}$ and ensiled $\mathrm{CP}+\mathrm{MO}$ were presented in Table 6 .

The means values of faecal nitrogen output (g/day) for rams fed control diet of ensiled cassava peels was 
Table 6. Nitrogen utilization of yankasa ram fed ensiled materials

\begin{tabular}{llllll}
\hline Parameters & CP & CP + GS & CP + LI & CP + M & SEM \\
\hline Mean live weight (kg) & 19.00 & 19.20 & 19.20 & 18.70 & 0.72 \\
Mean live weight (W. $\left.\mathbf{W}^{\mathbf{0 . 7 5}} \mathbf{K g}\right)$ & 9.10 & 9.17 & 9.17 & 8.99 & 0.82 \\
Nitrogen intake (g/day) & $5.04^{\mathrm{b}}$ & $7.93^{\mathrm{a}}$ & $7.98^{\mathrm{a}}$ & $7.60^{\mathrm{a}}$ & 0.62 \\
Faecal-N (g/day) & $1.05^{\mathrm{c}}$ & $2.36^{\mathrm{a}}$ & $2.38^{\mathrm{a}}$ & $2.16^{\mathrm{b}}$ & 1.01 \\
Digested-N (g/day) & $4.04^{\mathrm{b}}$ & $5.57^{\mathrm{a}}$ & $5.60^{\mathrm{a}}$ & $5.44^{\mathrm{a}}$ & 0.86 \\
Urinary-N (g/day) & $2.22^{\mathrm{a}}$ & $1.28^{\mathrm{a}}$ & $1.58^{\mathrm{c}}$ & $11.80^{\mathrm{b}}$ & 0.21 \\
N-Balance (g/day) & $1.82^{\mathrm{c}}$ & $4.29^{\mathrm{a}}$ & $4.02^{\mathrm{a}}$ & $3.64^{\mathrm{b}}$ & 0.38 \\
N-Retention (g/day) & 36.1 & 54.1 & 50.4 & 47.9 & 0.30 \\
\hline
\end{tabular}

$a, b, c$ Means with different superscript on the same row are significantly different $(P<0.05)$.

significantly $(p<0.05)$ lower $(1.05 \mathrm{~g} /$ day $)$ compared to those fed ensiled $\mathrm{CP}+\mathrm{GS}, \mathrm{CP}+\mathrm{LI}$ and $\mathrm{CP}+\mathrm{MO}$ that were $2.36,2.38$ and $2.16 \mathrm{~g} /$ day respectively.

The digested nitrogen ( $g /$ day) values for rams fed ensiled $\mathrm{CP}+\mathrm{GS}, \mathrm{CP}+\mathrm{LI}$ and $\mathrm{CP}+\mathrm{MO}$ were not significantly different $(P<0.05)$ but were significantly $(P<0.05)$ higher than the mean values for rams fed control diet of ensiled cassava peels only at (4.04 g/day).

The Nitrogen retention values for sheep fed ensiled $\mathrm{CP}+\mathrm{GS}, \mathrm{CP}+\mathrm{LI}$ were not significantly different $(P<0.05)$ but were significantly higher $(P<0.05)$ than the value for sheep fed ensiled CP + MO which in turn was significantly higher than the control diet of ensiled cassava peels only.

\section{DISCUSSION}

The proximate values of cassava peels ensiled only, obtained in this study are at variance with the result obtained by Ukanwoko and Ukandu (2011).

The cassava peels ensiled only used in this study

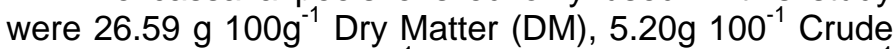
protein (CP), $18.56100 \mathrm{~g}^{-1}$ Crude fibre (CF), $0.86{\mathrm{~g} 100^{-1}}^{-1}$

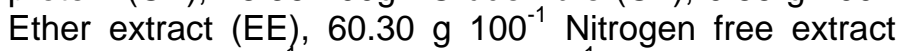

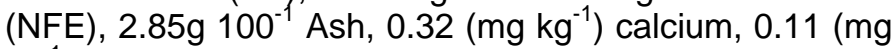
$\mathrm{kg}^{-1}$ ) phosphorus and $\mathrm{pH}$ of 5.1 .

The dry matter (DM) value of cassava peels ensiled only $26.59 \mathrm{~g} 100^{-1}$ obtained in this study is lower compared to $65.11 \mathrm{~g} 100^{-1}$ reported by Ukanwoko and Ukandu (2011). The crude fibre (CF) value of $18.56 \mathrm{~g} 100^{-1}$ ${ }^{1}$ was higher in comparison to the value of $17.21{\mathrm{~g} 100^{-1}}^{-1}$ obtained by Ukanwoko and Ukandu (2011). The crude

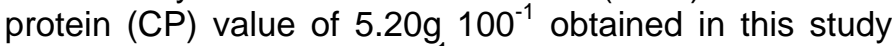

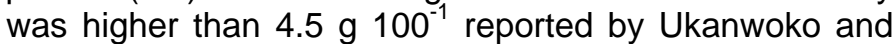
Ukandu (2011). The ether extract (EE) value obtained in this study $0.86{\mathrm{~g} 100^{-1}}^{-1}$ was in line with the ether extract

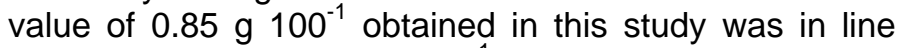

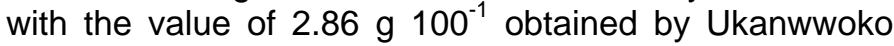
and Ukandu (2011). The values of calcium and phosphorus $0.32 \mathrm{Ca}\left(\mathrm{mg} \mathrm{kg}^{-1}\right), 0.11 \mathrm{P}\left(\mathrm{mg} \mathrm{kg}^{-1}\right)$ obtained in this study was lower compared to the values $0.85 \mathrm{Ca}(\mathrm{mg}$ $\left.\mathrm{kg}^{-1}\right), 0.14 \mathrm{P}\left(\mathrm{mg} \mathrm{kg}^{-1}\right)$ obtained by Ukanwoko and Ukandu (2011). The $\mathrm{pH}$ value (5.1) of the cassava peels ensiled only obtained in this study was higher than (4.32) reported by Ukanwoko and Ukandu (2011).

The difference in the values obtained from this study with those of other workers or researchers might be due to the stage of harvest of crops, soil types and processing method adopted.

\section{Rumen digestibility}

The higher nutrient digestibility in rams fed the supplemental diets of Gliricidia sepium ensiled with cassava peels, Leucaena leucocephala ensiled with cassava peels and Moringa oleifera ensiled with cassava peels indicates that the rumen functions were better than that of rams fed control diet of ensiled cassava peels. The significant higher nutrient in ensiled CP + GS, CP + $\mathrm{LI}$ and $\mathrm{CP}+\mathrm{MO}$ compared to the control diet of ensiled cassava peel only as observed in this study was due to the difference in the composition of treatments which appear to favour proper functioning of rumen micro organism in sheep under these treatments.

This result shows that the Yankasa sheep fed ensiled $\mathrm{CP}+\mathrm{GS}, \mathrm{CP}+\mathrm{LI}$ and $\mathrm{CP}+\mathrm{MO}$ respectively had a better rumen digestibility than those fed control diet of ensiled cassava peels.

\section{Feed intake}

The higher mean feed intake $(2.55+0.52)$ observed in rams fed control diet of ensiled cassava peels only compared to rams fed Gliricidia sepium ensiled with cassava peels, Leucaena leucocephala ensiled with cassava peels Moringa oleifera ensiled with cassava peels shows the detrimental effect of not ensiling cassava peels with either Gliricidia sepium, Leucaena leucocephala or Moringa oleiifera.

\section{Body weight changes}

The sheep fed control diet of ensiled cassava peels only in the study has lower relative weight gain hence, less 
body weights and metabolic live weight gains compared to sheep fed experimental diets of Gliricidia sepium, Leucaena leucocephala and Moringa oleiifera with cassava peels. This shows the effect of the treatment on weight gain and general production performance. The animals fed Gliricidia sepium, Leucaena leucocephala and Moringa oleiifera ensiled with cassava peels had higher weight gains $(2.4 \mathrm{~kg})$ in $\mathrm{CP}+\mathrm{GS},(2.2 \mathrm{~kg})$ in $\mathrm{CP}+$ $\mathrm{LI}$ and $(2.1 \mathrm{~kg})$ in $\mathrm{CP}+\mathrm{MO}$ compared with the weight gain in control $(1.8 \mathrm{~kg})$.

\section{CONCLUSION}

This study demonstrates that sheep fed Moringa oleiifera, Gliricidia sepium, and Leucaena leucocephala ensiled with cassava peels had better performance than those fed control diet of ensiled cassava peels only. This shows that ensiling Moringa oleiifera, Gliricidia sepium, and Leucaena leucocephala with cassava peels have enhance the performance of the sheep by efficiently improving the feed intake and digestibility of the animal.

This study clearly demonstrates that Moringa oleiifera, Gliricidia sepium, and Leucaena leucocephala ensiled with cassava peels in feeding ruminants is a strategy in overcoming dry season weight losses and poor performance in sheep fed cut and carry fodder.

\section{REFERENCES}

Akinbamijo OO, Adediran SA, Novala S, Saecker J(2004), Moringa fodder in ruminant nutrition in the Gambia. International Trypernotolerance Centre, Banjul, the Gambia.

AOAC (2005) Official Methods of Analysis. $16^{\text {th }}$ edu. (Association of Official Analytical Chemists Arlington, VA)

Aregheore EM(2002), Intake and Digestibility of Moringa olefiferaBatiki Grass Mixtures by Growing Goats. Small Ruminants Research46:23-28.

Aye PA(1998). The Effect of two Management System in some Physiological Parameters and Growth Rate of the West African Dwarf Goats (WAD) M. Tech Thesis Federal University of Technology, Akure, Nigeria. Pp.92.
Duncan DB(1955) Multiple Range and Multiple F Tests. Biometrics, 11:1-42

Ekpenyoung TE(1986)Nutrients and amino acid composition of Leucanaeleucophala. Anim. Feed Sci. and tech. 15:183-189.

Hassoun $P$, ba AA(1991). Mise all point d'nue technique de fabrication de blocks multinutrionnels sams me lasse.livestock Res.RuralDev., 2(2).

Makkar HPS, Becker(1996) Nutritional Value and Antinutritional Components of whole and Extracted Moringa oleifera leaves. Anim. Feed Sci. technol. 63,211-218.

Malini BP, Doss RG, Growda MKM, Golvindaiah MG(1989) Preliminary studies on the effects of feeding Leucaena leucocephala to rabbits. Leucaena Res. Reports Vol. 10:21-31.

Muriu JI, Njoka EN, Tuitoek JK, Nanna JN(2002). Evaluation of sorghum (sorghum bicolor) as replacement for maize in the diet of growing rabbits (oryctolagus cuniculus). Asian-Aust. J. Anim. Sci., 15 (4):546-569.

NAPRI (1984) Highlights of research Achievements on Animal Production. Science and Technology Briefing Lagos December 1984 pp. 3-17.

Nwaigwe CO, Nwankpa CA, Nwaigwe CU(2011) The effects of sawdust/ poultry litter and Brachiaria ruziziensis silages on the performance of West African Dwarf goats. Asian J. Biotechnol. 3:581-587

Peacock C, Devendra C, Ahuya C, Roets M, Hossain M, Osafo E (2005) Goats. In: Owen E, Kitalyt A, Jayasuriya N, Smith T (eds.) Livestock and Wealth Creation: Improving the husbandry of animals kept by resource-poor people in developing countries. Nottingham University Press, United Kingdom. Pp 361-385

Steel RGB, Torrie DH(1980) Principle and procedures of statistics. McGraw Hill Book Co. NY.

Ukanwoko Al, Ukandu C (2011) Continental J. Animal Production and Veterinary Res.3 (2) : 36-40. 